\title{
PENGARUH EFEKTIVITAS PROMOSI MELALUI INSTAGRAM DAN INOVASI PRODUK TERHADAP KEPUTUSAN PEMBELIAN
}

\author{
Henny Sulistiyowati ${ }^{1}$, Nuri Purwanto ${ }^{2 *}$ \\ ${ }^{1,2}$ Program Studi Manajemen STIE PGRI Dewantara Jombang \\ Jalan Prof. Yamin No. 77, Jombang \\ *Corresponding Author: nuri.stiedw@gmail.com
}

\begin{abstract}
This study aims to determine the effect of the effectiveness of promotion through instagram and product innovation on purchasing decisions for Gembul Banana products. The study was conducted because the results of several previous researchers found that product innovation and promotion are key factors in influencing purchasing decisions. The tight business competition that comes from businesses for similar products or substitute products, requires a business to always move faster and creatively to come up with new ideas in order to attract the attention of consumers. The method used in this research is descriptive explanatory method. Analysis of the data used using multiple linear regression analysis model. The population in this study were all buyers of Gembul Banana products by taking a sample of 101 respondents, and taking the sample using accidental sampling technique. The results showed that the effectiveness of promotion through instagram and product innovation had a positive effect on purchasing decisions for Gembul Banana products. Based on the results of this study, it is suggested to Gembul Banana business owners to be more serious in managing Gembul Banana social media, especially in posting photos, endeavor to post photos that are interesting and in accordance with consumer desires, not just photos and uploads on social media. In addition, it is also recommended that the logo of the company should be included on the packaging, not only in the form of a yellow box that is identical to a banana, but a logo must be included so that consumers can remember the product.
\end{abstract}

Keywords: effectiveness of promotion through instagram, product innovation, decisions purchase, Gembul Banana.

\begin{abstract}
ABSTRAK
Penelitian ini betujuan untuk mengetahui pengaruh efektivitas promosi melalui instagram dan inovasi produk terhadap keputusan pembelian produk Gembul Banana. Penelitian dilakukan karena dari hasil beberapa peneliti sebelumnya menemukan bahwa inovasi produk dan promosi merupakan faktor kunci dalam mempengaruhi keputusan pembelian. Ketatnya persaingan bisnis yang berasal dari
\end{abstract}


usaha untuk produk sejenis atau produk substitusi, menuntut suatu usaha agar selalu bergerak lebih cepat dan kreatif memunculkan ide-ide baru agar dapat menarik perhatian konsumen. Metode yang digunakan dalam penelitian ini adalah metode deskriptif eksplanatori. Analisis data yang digunakan mengunakan model analisis regresi linier berganda. Populasi dalam penelitian adalah semua pembeli produk Gembul Banana dengan mengambil sampel sebanyak 101 responden, dan pengambilan sampel menggunakan teknik accidental sampling. Hasil penelitian menunjukkan efektivitas promosi melalui instagram dan inovasi produk berpengaruh positif terhadap keputusan pembelian produk Gembul Banana. Berdasarkan hasil penelitian ini disarankan kepada pemilik usaha Gembul Banana agar lebih serius dalam mengelola sosial media Gembul Banana, terlebih lagi dalam posting foto, diusahakan posting foto yang menarik dan sesuai dengan keinginan konsumen, tidak hanya sekedar foto dan upload di sosial media. Di samping itu juga disarankan agar pada kemasan perlu dicantumkan logo dari perusahaan, tidak hanya bentuk kotak berwarna kuning yang identik dengan buah pisang, tetapi harus disertakan logo agar konsumen dapat mengingat produk tersebut.

Kata kunci: efektivitas promosi melalui instagram, inovasi produk, keputusan pembelian, Gembul Banana.

\section{PENDAHULUAN}

Berbagai macam jenis makanan bermunculan dengan ragam kreatifitas yang menarik. Makanan biasa dapat dikreasikan menjadi makanan yang memiliki cita rasa dan nilai jual tinggi. Salah satu makanan yang sering dijumpai adalah olahan pisang, contohnya adalah piscok, pisang goreng, nugget banana, kebab pisang, dan keripik pisang. Jenis makanan dengan bahan dari pisang ini cukup digemari oleh berbagai kalangan masyarakat, termasuk masyarakat di Jombang, Jawa Timur dan sekitarnya. Oleh karena itu banyak usaha yang bermunculan dengan bidang usaha kuliner berbahan dasar pisang ini. Sebagian besar usaha ini berbentuk UMKM (Usaha Mikro, Kecil, dan Menengah). Untuk dapat mampu bersaing dengan baik, UMKM di Jombang, Jawa Timur berusaha melakukan berbagai kreatifitas mengolah makanan berbahan dasar pisang tersebut agak bisa menjadi produk berbeda dan mempunyai nilai tambah. Salah satu produk UMKM olahan pisang yang ada di Jombang, Jawa Timur adalah Gembul Banana.

Untuk menjadikan usaha kuliner pisang digemari oleh masyarakat maka dalam bisnis persaingan kuliner, usaha kuliner perlu mempunyai strategi yang berbeda dengan pesaing seperti cara pengolahan pisang. Kuliner Gembul Banana merupakan olahan pisang yang telah dikreasi dengan bahan tambahan seperti tepung terigu dan tepung roti. Dengan cara pengolahan pisang yang berbeda dari produk sejenis, menjadikan Gembul Banana banyak diminati oleh konsumen. Ini terbukti dari jumlah porsi per bulan yang telah terjual. Hasil wawancara yang dilakukan dengan pemilik Gembul Banana pada tahun 2020 mengenai jumlah omzet penjualan Gembul Banana dalam periode 5 bulan terakhir seperti terlihat pada Tabel 1. 
Tabel 1

Omzet Penjualan Gembul Banana 5 Bulan Terakhir

\begin{tabular}{|c|c|c|c|}
\hline No & Bulan & $\begin{array}{c}\text { Jumlah Gembul Banana terjual (per } \\
\text { kotak) }\end{array}$ & Omset (Rp) \\
\hline 1. & Oktober & 839 & 21.168 .000 \\
\hline 2. & November & 881 & 22.456 .000 \\
\hline 3. & Desember & 987 & 25.536 .000 \\
\hline 4. & Januari & 963 & 23.660 .000 \\
\hline 5. & Februari & 928 & 22.272 .000 \\
\hline \multicolumn{2}{|r|}{ Total } & $\mathbf{4 . 5 9 8}$ & $\mathbf{1 1 5 . 0 9 2 . 0 0 0}$ \\
\hline
\end{tabular}

Sumber: Pemilik Gembul Banana

Menurut Kotler dan Amstrong (2001) keputusan pembelian adalah tahap dalam proses pengambilan keputusan pembelian di mana konsumen benar-benar membeli produk. Jadi keputusan pembelian merupakan sebuah proses konsumen melakukan proses pembelajaran terlebih dahulu akan sebuah produk sebelum melakukan proses pembelian. Keputusan pembelian timbul ketika konsumen itu belum mencoba atau menggunakan produk tersebut dan kemudian muncul perasaan puas dan belum puas. Untuk produk Gembul Banana, ketika konsumen melihat dan membaca produk olahan pisang yang di-posting di instragam gembulbanana.jbg dan di-posting dari foto atau pun video yang dikemas secara menarik, maka apabila konsumen tertarik, mereka akan secara otomatis mencari tahu produk tersebut dan pada akhirnya sampai konsumen membeli produk tersebut. Selain itu inovasi produk Gembul Banana juga sangat menentukan untuk membuat konsumen membeli atau tidak membeli produk tersebut, karena Gembul Banana dapat menciptakan olahan pisang yang unik.

Kotler dan Amstrong (2001) mengatakan bahwa e-marketing adalah sisi pemasaran dari e-commerce, yang merupakan kerja dari perusahaan untuk mengomunikasikan sesuatu, mempromosikan, dan menjual barang dan jasa melalui internet (Pradana, 2020). Dengan adanya e-marketing kita dapat membangun dan menjaga hubungan antara penjual dan pembeli serta menjadikan komunikasi lebih mudah tanpa harus bertatap muka secara langsung melainkan cukup hanya dengan menggunakan media gadget mulai dengan transaksi dan promosi produk, salah satu media tersebut adalah instagram. Efektivitas promosi menggunakan media instagram akan tercapai apabila sasaran yang sudah ditetapkan berhasil dengan tujuan tertentu. Efektivitas komunikasi dapat mempengaruhi keberhasilan bagi efektivitas media sosial sebagai media promosi. Efektivitas komunikasi adalah komunikasi yang dilancarkan sedemikian rupa sehingga menimbulkan efek kognitif, efektif, dan konatif pada komunikasi sesuai dengan tujuan komunikator (Uchjana dalam Luthfiyatillah et al., 2020). Untuk komunikasi produk Gembul Banana, ketika konsumen melihat dan membaca produk Gembul Banana yang diposting di instagram Gembul Banana dan di-posting foto atau pun video yang dikemas secara menarik, maka apabila konsumen tertarik, mereka akan secara 
otomatis mencari tahu produk tersebut dan pada akhirnya sampai konsumen membeli produk tersebut.

Inovasi produk adalah gabungan dari berbagai macam proses yang saling mempengaruhi antara satu dengan yang lain. Inovasi produk penting dilakukan sebagai faktor kunci mempengaruhi kepuasan konsumen (Fauziati dan Hasanah, 2019). Dalam situasi persaingan semakin ketat apalagi persaingan yang berasal dari perusahaan sejenis, menuntut suatu perusahaan agar selalu bergerak lebih cepat untuk menarik perhatian konsumen.

Hasil penelitian yang dilakukan oleh Khoernnikmah dan Widarko (2018) membuktikan bahwa internet marketing online yang terdiri dari variabel personal relevance, online interactivity berpengaruh secara persial terhadap keputusan pembelian. Sedangkan penelitian yang dilakukan oleh Rahayu (2018) menunjukkan bahwa inovasi produk merupakan pusat dari keberhasilan suatu bisnis, sehingga menuntut produsen makanan lebih inovatif dalam menghasilkan suatu produk, agar dapat menawarkan produk yang berbeda dengan para pesaing.

\section{TINJAUAN PUSTAKA}

\section{Keputusan Pembelian}

Keputusan pembelian adalah suatu tindakan maupun perilaku konsumen yang dapat menyebabkan terjadi atau tidaknya suatu proses pembelian. Banyak tidaknya jumlah konsumen dalam pengambilan keputusan menjadi salah satu faktor penentu tercapai tidaknya tujuan perusahaan (Firdaus, 2018). Sedangkan menurut Kotler dan Keller (2009) pengertian keputusan pembelian adalah tahap dalam proses pengambilan keputusan pembeli di mana konsumen benar-benar membeli. Pengambilan keputusan merupakan kegiatan individu yang secara langsung terlibat dalam mendapatkan dan menggunakan barang yang ditawarkan.

Kotler and Amstrong (2011) menjelaskan terdapat empat indikator dalam keputusan pembelian, yaitu:

1. Kemantapan sebuah produk

Dalam melakukan proses pembelian, konsumen akan memilih salah satu dari beberapa alternatif yang ada: kualitas yang baik, harga yang terjangkau, ataupun faktor-faktor lain yang akan membangun kepercayaan konsumen dan dapat memantapkan keinginan konsumen untuk membeli produk tersebut.

2. Kebiasaan dalam membeli produk

Kebiasaan konsumen dalam membeli produk juga berpengaruh terhadap keputusan pembelian. Konsumen merasa produk tersebut sudah melekat di benak mereka, karena mereka sudah merasakan akan manfaat dari produk tersebut. Oleh sebab itu, konsumen akan merasa tidak nyaman jika harus mencoba produk lain. Konsumen cenderung lebih memilih untuk produk yang sudah biasa digunakan.

3. Memberikan rekomendasi kepada orang lain.

Dalam melakukan proses pembelian, apabila seorang konsumen merasakan akan manfaat dari sebuah produk, mereka pasti akan merekomendasikan produk tersebut kepada orang lain. Mereka ingin seseorang juga merasakan manfaat akan produk tersebut. 
4. Melakukan pembelian ulang

Jika seseorang merasa sebuah produk tersebut cocok atau sesuai dengan yang diharapkan, tentunya konsumen merasa bahwa mereka puas. Apabila seorang konsumen merasa puas dalam menggunakan sebuah produk tersebut maka konsumen tersebut tentunya akan melakukan pembelian ulang.

\section{Efektivitas Promosi Melalui Instagram}

Efektivitas berhasil bila sasaran yang telah ditetapkan berhasil sesuai dengan tujuan tertentu. Semakin hasil mendekati tujuan yang diinginkan maka semakin tinggi derajat keefektivitasannya (Nafis, 2017). Efektivitas komunikasi dapat memengaruhi keberhasilan bagi efektivitas media sosial sebagai media promosi. Komunikasi pemasaran bisa dikatakan efektif apabila pemasar melancarkan kegiatan sedemikian rupa sehingga pembeli melewati tahap kognitif, afektif, dan perilaku (Nafis, 2017).

Menurut Luthfiyatillah, et al., (2020) iklan yang berhasil akan menimbulkan suatu tindakan dari konsumen yaitu berupa pembelian. Sebelum terjadinya pembelian terdapat indikator berupa tahapan-tahapan yang disebut hierarcy of effect (HOE). Hierarcy of effect adalah tingkatan pengaruh iklan terhadap konsumen. Teori hierarcy of effect yang paling terkenal adalah AIDA (attention, interest, desire, action) dengan penjelasan sebagai berikut:

1. Perhatian (attention) yaitu perhatian calon konsumen terhadap produk yang ditawarkan oleh produsen. Pesan yang ada harus menarik perhatian konsumen sasaran karena pesan yang mampu menarik perhatian yang akan dilihat oleh konsumen.

2. Ketertarikan (interest) yaitu ketertarikan calon konsumen terhadap produk yang ditawarkan oleh produsen. Setelah perhatian konsumen berhasil direbut, maka pesan harus dapat menimbulkan ketertarikan sehingga timbul rasa ingin tahu secara lebih rinci di dalam diri konsumen. Oleh karena itu harus dirangsang agar konsumen mau untuk mencoba.

3. Keinginan (desire) yaitu keinginan calon konsumen untuk memiliki produk yang ditawarkan oleh produsen. Pesan yang baik harus dapat mengetahui keinginan konsumen dalam pemaparan produk yang ditampilkan di pesan tersebut.

4. Tindakan (action), yaitu calon konsumen melakukan pembelian terhadap produk yang ditawarkan.

\section{Inovasi Produk}

Definisi mengenai pengertian inovasi produk adalah gabungan dari berbagai macam proses yang saling mempengaruhi antara yang satu dengan yang lain (Fauziati dan Hasanah, 2019). Sedangkan menurut Syahputra (2020) inovasi produk adalah sesuatu yang baru dari produk yaitu ide-ide yang dapat dirasakan oleh calon konsumen.

Ekasari dan Roza (2017) mengatakan bahwa indikator inovasi produk ada 3 yaitu:

1. Jenis produk

Menurut Ekasari dan Roza (2017) produk adalah sesuatu yang dapat ditawarkan ke pasar untuk diperhatikan, dipakai, dimiliki, atau dikonsumsikan sehingga 
dapat memuaskan keinginan atau kebutuhan. Dari pengertian ini dapat disimpulkan bahwa hampir semua yang termasuk produk adalah benda nyata yang dapat dilihat, diraba, dan dirasakan. Karena produk adalah benda riil, maka jenisnya cukup banyak. Secara garis besar jenis-jenis produk bisa kita perinci menjadi dua jenis yaitu produk konsumsi dan produk industri.

2. Peningkatan kualitas

Hansen and Mowen (2005) mendefinisikan kualitas sebagai berikut: "Quality is a relative measure of goodness". Definisi ini mengandung pengertian bahwa kualitas merupakan tingkat keunggulan (excellence) atau ukuran relatif dari kebaikan (goodness). Dari sekian banyak definisi kualitas yang ada, menurut Tjiptono dan Diana (2005) terdapat beberapa kesamaan yaitu dalam elemenelemen sebagai berikut:

a. Kualitas meliputi usaha memenuhi atau melebihi harapan pelanggan.

b. Kualitas mencakup produk, jasa, manusia, proses, dan lingkungan.

c. Kualitas merupakan kondisi yang selalu berubah (misalnya apa yang dianggap merupakan kualitas saat ini mungkin dianggap kurang berkualitas pada masa yang akan datang).

3. Kemasan fitur

Menurut Rundh (2005) pentingnya kemasan dan desain kemasan untuk memenuhi kriteria multi-fungsi yang berkaitan dengan logistik dan pemasaran dalam rantai pasokan yang diakhiri di tangan konsumen sehingga memunculkan fenomena perubahan pola konsumsi dan kebiasaan yang membutuhkan solusi kemasan yang inovatif di gerai ritel. Banyak perusahaan yang sangat memperhatikan kemasan suatu produk sebab perusahaan menganggap bahwa fungsi kemasan tidak hanya sebagai pembungkus tetapi lebih luas dari pada itu. Pengemasan harus mengandung fungsi daya tarik dan daya lindung. Perubahan kemasan sering pula memunculkan kesan dari konsumen karena mereka beranggapan bahwa barang yang di dalamnya juga ikut berubah. Oleh sebab itu suatu kemasan harus dibuat semenarik dan seaman mungkin (Darmawan, 2017).

\section{Hipotesis Penelitian}

Penelitian yang dilakukan merupakan penelitian kuantitatif untuk pengujian hipotesis. Ada 2 hipotesis yang akan diuji di dalam penelitian ini, yaitu:

H1 : Efektivitas promosi melalui instagram berpengaruh terhadap keputusan pembelian Gembul Banana.

$\mathrm{H} 2$ : Inovasi produk berpengaruh terhadap keputusan pembelian Gembul Banana.

\section{METODE PENELITIAN}

\section{Rancangan Penelitian}

Penelitian ini menggunakan metode kuantitatif dengan tujuan untuk menguji hipotesis. Jenis penelitian ini adalah explanatory research, sedangkan teknik analisis data yang digunakan adalah regresi linier berganda. Pada penelitian ini menggunakan skala Likert (1-5). Penelitian ini dilakukan pada pelanggan Gembul Banana. Adapun objek penelitian adalah pelanggan Gembul Banana yang melakukan pemesanan via online. 


\section{Sumber Data dan Teknik Pengambilan Data}

Sumber data primer yang diperoleh dalam penelitian ini diperoleh melalui kuesioner yang diberikan kepada pelanggan Gembul Banana yang melakukan pemesanan pembelian melalui media online. Sedangkan sumber data sekundernya bersumber dari buku, internet, jurnal ilmiah, laporan penelitian, skripsi, tesis, dan media massa. Untuk teknik pengambilan datanya dilakukan melalui penyebaran kuesioner.

\section{Populasi dan Sampel}

Populasi adalah gabungan dari seluruh elemen yang berbentuk peristiwa, hal, atau orang yang memiliki karakteristik serupa yang menjadi pusat perhatian seorang peneliti karena itu dipandang sebagai semesta penelitian (Ferdinand, 2014). Populasi dalam penelitian ini adalah berjumlah 4.121 orang. Jumlah ini berasal dari total jumlah followers yang mengikuti Gembul Banana di instagram.

Untuk membuktikan kebenaran jawaban yang masih sementara (hipotesis), maka peneliti melakukan pengumpulan data pada objek tertentu. Karena objek dalam populasi terlalu luas, maka peneliti menggunakan sampel yang diambil dari populasi tersebut. Menurut Sugiyono (2013) sampel adalah bagian dari jumlah dan karakteristik yang dimiliki oleh populasi tersebut.

Dalam penelitian ini jumlah populasinya diketahui sejumlah 4.121 orang maka besarnya sampel ditentukan menggunakan teknik pengambilan sampel dengan rumus Taro Yamane atau Slovin. Berikut rumus pengambilan sampel menggunakan rumus Slovin (Ayuningtyas, 2016):

$$
\mathrm{n}=\frac{N}{N \cdot d^{2}}+1
$$

\section{Keterangan :}

$$
\begin{array}{ll}
\mathrm{N} & =\text { Jumlah sampel } \\
\mathrm{N} & =\text { Jumlah populasi } \\
\mathrm{d}^{2} & =\text { Presisi (ditetapkan 10\%) }
\end{array}
$$

Dari rumus tersebut diperoleh jumlah sampel sebagai berikut:

$$
\mathrm{n}=\frac{4121}{4121.0,01}+1=101
$$

Berdasarkan perhitungan di atas, maka besarnya nilai sampel sebesar 101 orang dengan kriteria sampel pelanggan yang menggunakan dan membeli produk Gembul Banana dan melakukan transaksi jual beli produk Gembul Banana satu kali via online melalui media instagram. Dalam penelitian ini metode penetapan sampelnya menggunakan teknik probability sampling, merupakan teknik pengambilan sampel dipilih secara acak (Ferdinand, 2014). Sedangkan teknik pengambilan sampelnya menggunakan teknik accidental sampling yaitu metode sampel dengan cara mengumpulkan data melalui siapa saja yang ditemui oleh peneliti di akun instagram Gembul Banana tahun 2020 dan menjadi followers Gembul Banana 


\section{HASIL PENELITIAN DAN PEMBAHASAN}

\section{Hasil Penelitian}

\section{Karakteristik Responden}

Penelitian ini dilakukan pada konsumen Gembul Banana yang terdapat di instagram Gembul Banana dengan sampel sebanyak 101 konsumen. Berikut ini peneliti sajikan karakteristik responden sebagai berikut:

1. Mayoritas responden berdasarkan usia adalah rentang usia 18-30 tahun dengan jumlah sebanyak 62 orang atau sebesar 61,4 \%. Pada usia 18-30 tahun merupakan usia yang masih tergolong muda karena masih senang dengan berkuliner, selain itu dikarenakan lokasi Gembul Banana dekat dengan tempat anak muda nongkrong seperti Stadion Jombang, Terminal Ploso.

2. Mayoritas responden berdasarkan pekerjaan adalah lainnya, seperti pelajar dan mahasiswa dengan jumlah frekuensi 50 responden atau 49,5\%. Hal ini dikarenakan pelajar dan mahasiswa antusias mencoba hal yang baru seperti menu baru olahan pisang yang berbeda dari sebelumnya contohnya Gembul Banana.

\section{Hasil Uji Validitas dan Reliabilitas}

Hasil uji validitas dan reliabilitas dari penelitian ini nampak seperti terlihat pada Tabel 2 dan Tabel 3.

Tabel 2

Hasil Uji Validitas

\begin{tabular}{|c|c|c|c|c|}
\hline Variabel & Item & Nilai Korelasi & Batas Korelasi & Keterangan \\
\hline \multirow{4}{*}{$\begin{array}{c}\text { Efektivitas } \\
\text { Promosi Melalui } \\
\text { Instagram (X1) }\end{array}$} & $\mathrm{X} 1.1$ & 0,739 & 0,30 & Valid \\
\hline & $\mathrm{X} 1.2$ & 0,667 & 0,30 & Valid \\
\hline & $\mathrm{X} 1.3$ & 0,646 & 0,30 & Valid \\
\hline & $\mathrm{X} 1.4$ & 0,845 & 0,30 & Valid \\
\hline \multirow{5}{*}{$\begin{array}{l}\text { Inovasi Produk } \\
\text { (X2) }\end{array}$} & $\mathrm{X} 2.1$ & 0,818 & 0,30 & Valid \\
\hline & $\mathrm{X} 2.2$ & 0,660 & 0,30 & Valid \\
\hline & $\mathrm{X} 2.3$ & 0,762 & 0,30 & Valid \\
\hline & $\mathrm{X} 2.4$ & 0,572 & 0,30 & Valid \\
\hline & $X 2.5$ & 0,724 & 0,30 & Valid \\
\hline \multirow{4}{*}{$\begin{array}{c}\text { Keputusan } \\
\text { Pembelian (Y) }\end{array}$} & Y1.1 & 0,936 & 0,30 & Valid \\
\hline & Y1.1 & 0,478 & 0,30 & Valid \\
\hline & Y1.1 & 0,957 & 0,30 & Valid \\
\hline & Y1.1 & 0,951 & 0,30 & Valid \\
\hline
\end{tabular}

Sumber: Output SPSS 25 - Hasil Uji Validitas dan Reliabilitas

Dari hasil pada Tabel 2 dapat disimpulkan bahwa semua butir pertanyaan diperoleh dari nilai korelasi lebih besar dari nilai koefesien, hal ini berarti semua variabel adalah valid. 
Tabel 3

Hasil Uji Reliabilitas

\begin{tabular}{|c|c|c|c|}
\hline Variabel & Cronbach Alpha & Koefisien $\boldsymbol{\alpha}$ & Keterangan \\
\hline $\begin{array}{c}\text { Efektivitas Promosi } \\
\text { Melalui Instagram (X1) }\end{array}$ & 0,784 & 0,6 & Reliabel \\
\hline $\begin{array}{c}\text { Inovasi Produk (X2) } \\
\text { Keputusan Pembelian }\end{array}$ & 0,777 & 0,6 & Reliabel \\
\hline (Y) & 0,825 & 0,6 & Reliabel \\
\hline
\end{tabular}

Sumber: Output SPSS 25 - Hasil Uji Validitas dan Reliabilitas

Dari hasil pada Tabel 3 dapat disimpulkan bahwa hasil pengujian reliabilitas dapat dikatakan reliabel karena dapat dilihat dari Cronbach Alpha > 0,6. Dengan ini maka variabel efektifitas promosi melalui instagram (X1) memiliki nilai Cronbach Alpha 0,784 > 0,6 maka dikatakan reliabel, variabel inovasi produk (X2) memiliki nilai Cronbach Alpha sebesar 0,777 > 0,6 maka dikatakan reliabel dan variabel keputusan pembelian (Y) memiliki nilai Cronbach Alpha sebesar 0,825 > 0,6 maka dapat dikatakan reliabel. Jadi ketiga variabel tersebut dapat dikatakan reliabel.

\section{Uji Asumsi Klasik}

Untuk melakukan analisis menggunakan regresi berganda mengharuskan pengujian asumsi klasik terlebih dahulu terhadap data yang digunakan. Pada penelitian dilakukan pengujian asumsi klasik yang terdiri dari uji normalitas, uji heteroskedastisitas, dan uji multikoliniertas yang hasil pengujiannya seperti terlihat pada Gambar 1, Gambar 2, dan Tabel 4.

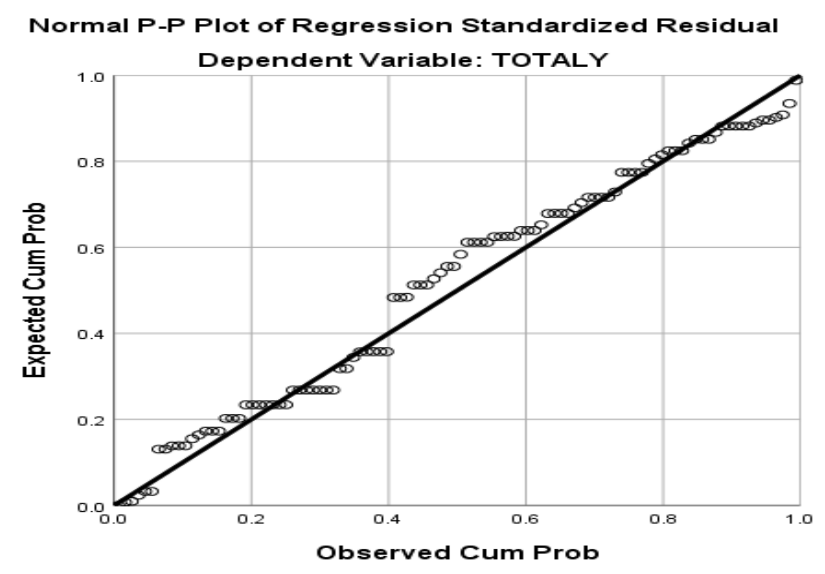

Sumber: Output SPSS 25

\section{Gambar 1 \\ Grafik Hasil Uji Normalitas Data}

Dari Gambar 1 dapat dilihat bahwa data (titik-titik) menyebar di sekitar garis diagonal yang berarti data tersebut berdistribusi secara normal. Jadi penelitian ini dapat dilanjutkan pada analisis berikutnya, karena mematuhi asumsi normalitas. 


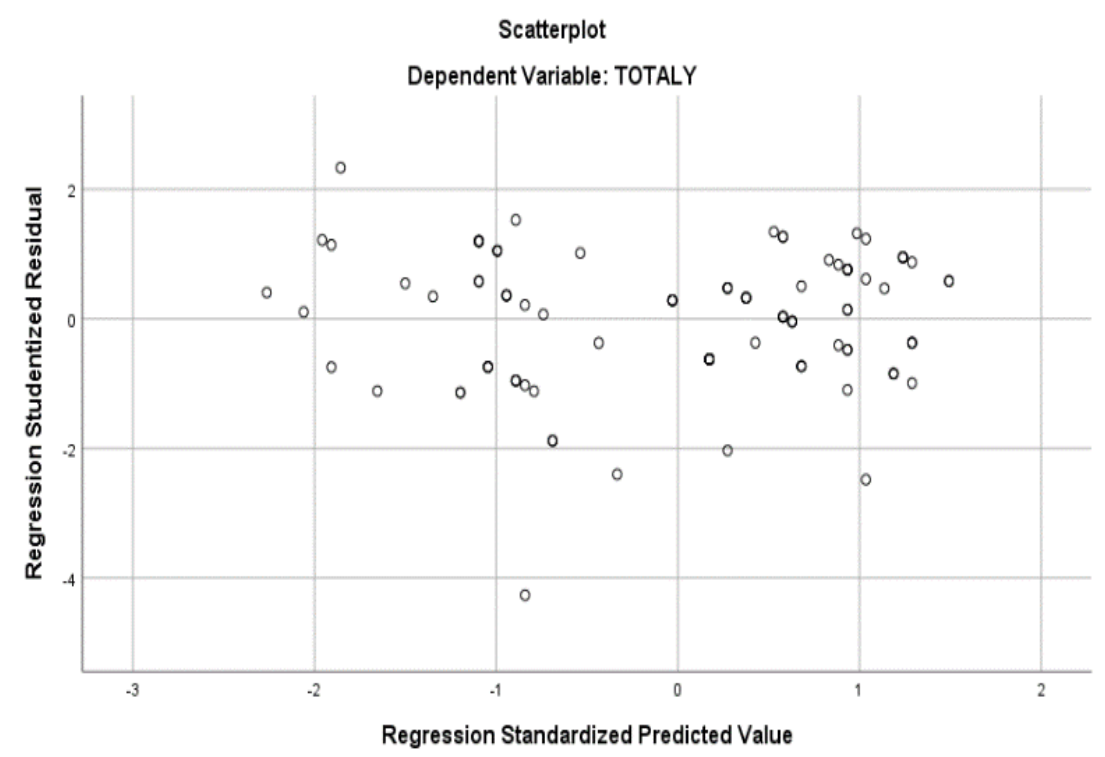

Sumber: Output SPSS 25

Gambar 2

Grafik Scatterplot Hasil Uji Heteroskedastisitas

Gambar 2 menunjukkan bahwa tidak ada pola yang jelas, artinya model regresi ini dapat dikatakan tidak terjadi Heteroskedastisitas, sehingga model regresi tersebut layak digunakan.

\section{Tabel 4}

\section{Hasil Uji Multikolinearitas}

\begin{tabular}{|l|c|c|l|}
\multicolumn{1}{|c|}{ Variabel } & Nilai Toleransi & VIF & \multicolumn{1}{c|}{ Keterangan } \\
\hline $\begin{array}{l}\text { Efektivitas } \\
\text { Promosi Melalui }\end{array}$ & 0,464 & 2,155 & $\begin{array}{l}\text { Tidak Terjadi } \\
\text { Multikolinieritas }\end{array}$ \\
\hline Instagram & & & Mution \\
\hline Inovasi Produk & 0,464 & 2,155 & $\begin{array}{l}\text { Tidak Terjadi } \\
\text { Multikolinieritas }\end{array}$ \\
\hline
\end{tabular}

Sumber: Output SPSS 25

Pada Tabel 4 dapat dilihat bahwa nilai toleransi lebih besar dari 0,01 yang berarti bebas dari masalah multikolinieritas dan hasil perhitungan VIF juga menunjukkan hal yang sama yaitu variabel independen memiliki nilai VIF kurang dari 10. Dengan demikian dapat disimpulkan bahwa tidak terjadi multikolinieritas antar variabel independen dalam model regresi penelitian ini.

\section{Hasil Uji Analisis Regresi Linear Berganda}

Hasil uji analisis regresi linier berganda dengan menggunakan software SPSS 25 nampak seperti terlihat pada Tabel 5. 
Tabel 5

Hasil Uji Analisis Regresi Linier Berganda

\begin{tabular}{|c|c|c|c|c|}
\hline Variabel & $\begin{array}{c}\text { Unstandardized } \\
\text { Coeffisients }\end{array}$ & t hitung & Sig & Keterangan \\
\hline Constant & 2,067 & 2,122 & 0,036 & Signifikan \\
\hline $\begin{array}{c}\text { Efektivitas Promosi } \\
\text { Melalui Instagram } \\
\text { (X1) }\end{array}$ & 0,588 & 7,276 & 0,000 & Signifikan \\
\hline \begin{tabular}{c} 
Inovasi Produk (X2) \\
\hline
\end{tabular} & 0,236 & 3,048 & 0,003 & Signifikan \\
\hline
\end{tabular}

Sumber: Output SPSS 25 - Hasil Uji Regresi Linier Berganda

Variabel terikat pada regresi ini adalah Y, sedangkan variabel bebasnya adalah X1 dan X2. Berdasarkan hasil analisis di atas diperoleh persamaan sebagai berikut:

$$
\mathrm{Y}=2,067+0,588 \mathrm{X}_{1}+0,236 \mathrm{X}_{2}
$$

Hasil persamaan regresi di atas menunjukkan bahwa efektivitas promosi melalui instagram dan inovasi produk berpengaruh positif dan signifikan terhadap variabel keputusan pembelian.

\section{Hasil Uji Koefisien Determinasi $\left(\mathbf{R}^{2}\right)$}

Uji koefisien determinasi $\left(\mathrm{R}^{2}\right)$ menunjukkan hasil seperti terlihat pada Tabel 6 berikut ini.

Tabel 6

Hasil Uji Koefisien Determinan $\left(\mathbf{R}^{2}\right)$

\begin{tabular}{|l|c|r|r|r|r|}
\hline Model & $\mathbf{R}$ & $\begin{array}{c}\mathbf{R} \\
\text { Square }\end{array}$ & $\begin{array}{c}\text { Adjusted } \\
\text { R Square }\end{array}$ & $\begin{array}{c}\text { Std. Error } \\
\text { of the } \\
\text { Estimate }\end{array}$ & $\begin{array}{c}\text { Durbin- } \\
\text { Watson }\end{array}$ \\
\hline 1 & 0,821 & 0,673 & 0,667 & 1,631 & 1,820 \\
\hline
\end{tabular}

Sumber: Output SPSS 25

Tabel 6 menunjukkan bahwa nilai $\mathrm{R}^{2}$ sebesar 0,673 artinya keputusan pembelian Gembul Banana berdasarkan hasil analisis ini dipengaruhi oleh efektivitas promosi melalui instagram dan inovasi produk sebesar $67,3 \%$. Sedangkan sisanya, yaitu sebesar $32,7 \%$ dipengaruhi oleh faktor lain yang tidak diteliti dalam penelitian ini.

\section{Uji t}

Uji t dilakukan untuk mengetahui pengaruh parsial masing-masing variabel efektivitas promosi melalui instagram dan inovasi produk terhadap variabel keputusan pembelian. Hasil uji t seperti terlihat pada Tabel 7. 


\section{Tabel 7}

Hasil Uji t

\begin{tabular}{|c|c|c|c|}
\hline Variabel & Nilai t & Signifikasi & Tabel t \\
\hline $\begin{array}{c}\text { Efektivitas } \\
\text { Promosi Melalui } \\
\text { Instagram }\end{array}$ & 7,276 & 0,000 & 1,983 \\
\hline Inovasi Produk & 3,048 & 0,003 & 1,983 \\
\hline
\end{tabular}

\section{Sumber: Output SPSS 25}

Tabel 7 menunjukkan hasil pengujian untuk hipotesis yang pertama dengan menggunakan uji $\mathrm{t}$ yaitu pengujian parsial antara efektivitas promosi melalui instagram terhadap keputusan pembelian Gembul Banana. Variabel efektivitas promosi melalui instagram (X1) memiliki nilai hitung t sebesar 7,276 $>\mathrm{t}$ tabel sebesar 1,983 dan tingkat signifikan $\mathrm{t}$ lebih kecil dari 0,05 (sig. $\mathrm{t}=0,000<0,05$ ) maka $\mathbf{H 1}$ diterima, artinya efektivitas promosi melalui instagram berpengaruh positif dan signifikan terhadap keputusan pembelian Gembul Banana. Pengujian hipotesis yang kedua adalah inovasi produk (X2) yang memiliki nilai t hitung sebesar 3,048 $>\mathrm{t}$ tabel sebesar 1,983 dan tingkat signifikan $\mathrm{t}$ lebih kecil dari 0,05 (sig. $\mathrm{t}=0,003<0,05$ ), sehingga $\mathbf{H 2}$ diterima, artinya inovasi produk berpengaruh positif dan signifikan terhadap keputusan pembelian Gembul Banana.

\section{Pembahasan}

Pengaruh efektivitas promosi melalui instagram di Gembul Banana dapat dilihat dari promosi yang langsung berhubungan dengan konsumen karena produk Gembul Banana tercermin dalam posting di instagram. Untuk menumbuhkan kepercayaan dari pengguna instagram bio dilengkapi informasi seputar outlet Gembul Banana Jombang dan cara order yang sudah tertera di instagram, sehingga dapat mempermudah konsumen untuk membeli.

Username yang digunakan oleh Gembul Banana singkat, jelas, dan mudah diingat oleh konsumen. Selain itu postingan dan story instagram Gembul Banana selalu konsisten agar mudah dilihat oleh follower, sehingga bisa terjadi antara keduanya seperti like, komen maupun share. Dengan terjadinya interaksi ini secara tidak langsung mem-branding Gembul Banana semakin dikenal oleh orang banyak..

Menurut Luthfiyatillah et al. (2020) iklan yang berhasil akan menimbulkan suatu tindakan dari konsumen yaitu berupa pembelian, sebelum terjadinya pembelian melalui tahapan-tahapan yang disebut hierarcy of effect (HOE). Hasil penelitian ini memperkuat penelitian sebelumnya yang dilakukan oleh Huda dan Prasetyo (2019) bahwa efektivitas promosi melalui instagram berpengaruh terhadap keputusan pembelian.

Berdasarkan hasil analisis yang peneliti lakukan maka dapat dijelaskan bahwa inovasi produk berpengaruh terhadap keputusan pembelian Gembul Banana Jombang. Hasil pengujian menunjukkan bahwa pengaruh inovasi produk terhadap 
keputusan pembelian Gembul Banana sangat tinggi dan sesuai dengan yang diharapkan. Dengan demikian, jika inovasi layanan semakin menarik maka keputusan pembelian akan meningkat.

Menariknya inovasi produk di Gembul Banana Jombang dapat dilihat dari jenis produk. Ada 3 jenis produk diantaranya crispy, nugget, dan piscok lumer. Inovasi dari segi kemasan yang digunakan Gembul Banana saat pertama melakukan penjualan sangat berbeda dengan yang sekarang. Dahulu Gembul Banana dalam mengemas produknya hanya memakai kardus putih dengan stiker tempel logo produk. Seiring berjalannya waktu Gembul Banana melakukan perubahan kemasan dengan mendesain kardus dengan menambahkan logo dan gambar pisang supaya lebih menarik.

Menurut Syahputra (2020) inovasi produk adalah sesuatu yang baru dari produk yaitu ide-ide yang dapat dirasakan oleh calon konsumen. Hasil penelitian Syahputra (2020) memperkuat penelitian sebelumnya yang dilakukan oleh Ekasari dan Roza (2017) yang menunjukkan bahwa inovasi produk berpengaruh terhadap keputusan pembelian.

\section{SIMPULAN}

Efektivitas promosi melalui instagram berpengaruh terhadap keputusan pembelian produk Gembul Banana. Promosi yang dilakukan Gembul Banana di instagram sangat menarik. Menariknya promosi melalui instagram di Gembul Banana dapat dilihat dari promosi yang langsung berhubungan dengan konsumen karena produk Gembul Banana tercermin dalam postingan di instagram. Semakin menarik tampilan yang diperlihatkan ke konsumen maka konsumen akan tertarik dan membelinya. Jadi dengan demikian, jika promosi melalui instagram semakin menarik maka keputusan pembelian akan meningkat.

Inovasi produk berpenagruh terhadap keputusan pembelian produk Gembul Banana. Semakin banyak inovasi dan kreasi yang dilakukan terhadap produk di Gembul Banana Jombang yang dapat dilihat dari jenis produk, peningkatan kualitas, dan kemasan. Variasi produk Gembul Banana sangat beragam antara lain crispy dan nugget yang berbahan utamanya adalah pisang ambon, sehingga dengan banyaknya variasi produk Gembul Banana konsumen bebas memilih sesuai dengan selera mereka. Selain itu kemasan Gembul Banana sesuai dengan produk yang dijual dengan memberikan gambar pisang yang menarik perhatian konsumen untuk membelinya. Jadi dengan demikian, jika banyak inovasi produk yang dilakukan maka keputusan pembelian akan meningkat.

\section{SARAN}

Bagi Gembul Banana sebaiknya dalam mem-posting produk di instagram seharusnya lebih diperhatikan lagi dalam hal pengambilan gambar produk Gembul Banana dan pengeditan seperti diberikan filter, animasi, dan kata-kata yang menarik. Di samping itu pada tampilan kemasan produk Gembul Banana sebaiknya ditambahkan gambar produk asli dari Gembul Banana agar lebih menarik. Untuk peneliti selanjutnya diharapkan dapat meneliti tentang keputusan pembelian pada ranah online dengan variabel lain dan objek yang berbeda. 


\section{DAFTAR PUSTAKA}

Ayuningtyas, Locana Dewi. 2016. Pengaruh Harga, Promosi, Merek, dan Kualitas Produk Terhadap Keputusan Pembelian Jilbab Ezatta di Royal Plaza Surabaya. Jurnal Pendidikan Tata Niaga (JPTN), Vol. 3, No. 2, pp. 1-15.

Darmawan, Didit. 2017. Pengaruh Kemasan dan Harga Terhadap Keputusan Pembelian Produk Sayuran Hidroponik. Agrimas, Vol. 1, No. 1, pp. 1-10.

Ekasari, Novita dan Suswita Roza. 2017. Pengaruh Inovasi Produk Terhadap Keputusan Pembelian Konsumen Bisnis pada UMKM Keripik Pisang Dharma Jaya. Jurnal Manajemen Terapan dan Keuangan, Vol. 6, No. 3, pp. 195-207.

Fauziati, Hanifah Amelia dan Nurjannatul Hasanah. 2019. Pengaruh Inovasi Produk dan Desaign Rumah Makan Terhadap Kepuasan Konsumen (Studi Kasus pada Kedai Ohayo Kota Trarakan). Jurnal Ekonomika, Vol. 10, No. 1, pp. $1-12$.

Ferdinand, Augusty Tae. 2014. Metodologi Penelitian Manajemen. Badan Penerbit Universitas Diponegoro. Semarang.

Firdaus, Azizi. 2018. Analisis Faktor-Faktor yang Mempengaruhi Keputusan Pembelian pada Go-Food di Kota Surabaya. Repository STIE PGRI Dewantara Jombang. Skripsi. http://repository.stiedewantara.ac.id/id/eprint/37.

Hansen, D. R. and M. M. Mowen. 2005. Management Accounting. Sixth Edition. Thomson Learning. United States Of America.

Huda, Miftahul dan Anton Prasetyo. 2019. Efektivitas Promosi Melalui Media Sosial pada UMKM Produk Gethuk Pisang Terhadap Keputusan Pembelian di Kabupaten Kebumen. Proceeding Seminar Nasional dan Call For Papers. Management Dynamic Conference, Vol. 5 (Madic 5).

Khoernnikmah, Iik dan Agus Widarko. 2018. Online Marketing Influence On Decision Purchase Consumer.

Kotler, Philip dan Gary Amstrong. 2001. Prinsip-Prinsip Pemasaran (Terjemahan). Erlangga. Jakarta.

Kotler, Philip and Gary Amstrong. 2011. Marketing. Pearson Education. New Jersey.

Kotler, Philip dan Kevin Lane Keller. 2009. Manajemen Pemasaran. Edisi Revisi 13. Jilid 1. Erlangga. Jakarta.

Luthfiyatillah, Afifah Nur Millatina, Sitti Hamidah Mujahidah, dan Sri Herianingrum. 2020. Efektifitas Media Instagram dan E-Wom (Electronic Word of Mouth) Terhadap Minat Beli serta Keputusan Pembelian. Jurnal Penelitian Ipteks, Vol. 5, No. 1, pp. 101-115. 
Nafis, A. G. R. 2017. Efektivitas Media Sosial Instagram Sebagai Media Promosi Pada Produk Jilbab Afra. Skripsi. UIN Walisongo.

Pradana, V. A. 2020. Pengaruh Pemasaran Online dan Inovasi Layanan Terhadap Keputusan Pembelian (Studi Kasus Produk Love Bird SimbahBF). Skripsi. STIE Dewantara Jombang. Skripsi. http://repository.stiedewantara.ac.id/id/eprint/ 1193.

Rahayu, S. 2018. Pengaruh Inovasi Produk dan Harga Terhadap Keputusan Pembelian (Studi Kasus Telur Asin Dikelurahan Limbangan Wetan Kabupaten Brebes).

Rundh, Bo. 2005. The Multi-Faceted Dimansion of Packaging. British Food Journal. Vol. 107, No. 9, pp. 607-684.

Sugiyono. 2013. Metode Penelitian Bisnis (Pendekatan Kuantitatif, Kualitatif, dan $R \& D)$. Alfabeta. Bandung.

Syahputra, Haries Alnanda. 2020. Peran Inovasi Produk dan Celebrity Endorser Terhadap Keputusan Pembelian Sepatu Nike pada Pengunjung Outlet Nike di Tunjungan Plaza Surabaya. Jurnal Ilmu Manajemen Universitas Negeri Surabaya. Vol. 8, No. 1, pp. 1-9.

Tjiptono, Fandy dan Anastasia Diana. 2005. Total Quality Management. Edisi Revisi. Andi. Yogyakarta. 